\title{
Characterization of hydrogenated fats for margarine manufacturing purposes
}

\author{
By Renato Grimaldi ${ }^{1}$, Renata Tieko Nassu ${ }^{2}$, Lireny Aparecida Guaraldo \\ Gonçalves ${ }^{1}$ and Rosana Nogueira Cavaletti Moreira ${ }^{1}$
}

\author{
'Laboratorio de Óleos e Gorduras - Faculdade de Engenharia de Alimentos (FEA) - \\ Universidade Estadual de Campinas (UNICAMP), Caixa Postal 6091 \\ CEP 13081-970, Campinas, SP, Brazil. \\ ${ }^{2}$ Centro Nacional de Pesquisa de Agroindústria Tropical (CNPAT) /EMBRAPA -
}

Rua Dra. Sara Mesquita, 2270 - Bairro Planalto Pici, CEP 60511-110, Fortaleza, CE, Brazil.

\section{RESUMEN}

Caracterización de aceites hidrogenados para la fabricación de margarinas.

Ocho muestras de aceites vegetales hidrogenados fueron caracterizados por su composición en ácidos grasos, contenido de isómeros trans y comportamiento térmico, usando las técnicas de cromatografía gaseosa (CG), espectroscopia infrarrojo (IR), Resonancia Magnética Nuclear Pulsante (pRMN), Calorimetría Diferencial de Barrido (DSC), respectivamente. La composición en ácidos grasos mostró algunas variaciones respecto a los ácidos grasos insaturados. El contenido en isómeros trans varió de valores de 22,8 a $35,6 \%$. El valor del contenido en grasa sólido fue medido usando los métodos de la AOCS y IUPAC, que difieren en los procedimientos de atemperado. Los valores obtenidos por el método IUPAC fueron mayores que los obtenidos por el de AOCS, sólo a bajas temperaturas $\left(10 \mathrm{a} 21.1^{\circ} \mathrm{C}\right)$. Las muestras fueron divididas en tres grupos de acuerdo con su perfil de sólidos: superior $(C / E / G / H)$, intermedio $(F)$ e inferior $(A / B / D)$. Las curvas de fusión y cristalización fueron obtenidas con Calorimetría Diferencial de Barrido. Las entalpias de fusión estaban en rangos de 51,3 a $76,5 \mathrm{~J} . \mathrm{g}^{-1}$ y las entalpias de cristalizacion varió de $-34,1$ a $-18,9 \mathrm{J.g}^{-1}$. Las temperaturas características mostraron poca diferencia entre las muestras y cada una de ellas mostró una curva DSC típica. Todas las muestras mostraron un excelente rango de fusión como es de esperarse de los aceites hidrogenados para la fabricación de margarinas.

PALABRAS-CLAVE: Aceite hidrogenado - Acido graso (composición en) - Comportamiento térmico - Isómeros trans - Margarina (fabricación).

\section{SUMMARY}

Characterization of hydrogenated fats for margarine manufacturing purposes.

Eight samples of hydrogenated vegetable fats were characterized by their fatty acid composition, trans isomers content and thermal behaviour, using gas chromatography (GC), infrared spectroscopy (IR), pulsed Nuclear Magnetic Resonance (pNMR) and Differential Scanning Calorimetry (DSC) techniques, respectively. Fatty acid composition showed some variations in relation to the unsaturated fatty acids. Trans isomer content, values varied from $22.8 \%$ to $35.6 \%$. Solid fat content values were measured using AOCS and
IUPAC methods, which differ in the tempering procedures. Values obtained by IUPAC method were higher than the AOCS ones, only at lower temperatures $\left(10\right.$ and $\left.21,1^{\circ} \mathrm{C}\right)$. Samples were divided into three groups according to their solids profile: superio $(C / E / G / H)$ intermediate $(F)$ and inferior $(A / B / D)$. Melting and crystallization curves were obtained by Differential Scanning Calorimetry. Melting enthalpies ranged from 51.3 to $76.5 \mathrm{J.g}$ and crystallization enthalpies varied from -34.2 to $-18.9 \mathrm{~J}^{-1} \mathrm{~g}^{-1}$. Characteristic temperatures showed little differences between the samples and each of them showed a characteristic DSC curve. All samples showed a great melting range as expected for hydrogenated fats used for margarines manufacture.

KEY-WORDS: Fatty acid (composition in) - Hidrogenated oil Margarine (manufacture) - Thermal behaviour - Trans isomers.

\section{INTRODUCTION}

Hydrogenation process is one of the most important tool in margarines and vegetable specialty fats production. This process aim to reduce unsaturation degree and the melting point of oils. Through a careful choice of the catalyzer and temperature, oil can be hydrogenated selectively, reaching the desirable characteristics for the product. In these conditions, the hydrogenation process lead to production of trans isomers forms of fatty acids (Valenzuela et al., 1995).

Hydrogenated vegetable fats manufacturers use trans isomers to prepare specialty fats because of the thermal behaviour of such fats. The presence of these products change physical and thermal characteristics of formulated products. Safety about ingestion of trans fatty acids has been widely discussed. Although some controversy about the effects to health, lowering consumption of trans isomers is advisable. Several alternatives have been proposed, such as formulation of hydrogenated fats without trans (zero-trans), through the blending of completely saturated fats and vegetable oils, or specialty fats produced by the 
interesterification or fractionation processes (BarreraArellano \& Block, 1993).

The choice of which fat to use in the food industry depends on its thermal behaviour. This property is directly influenced by the fatty acid composition, trans isomers content and solid fat content. For solid fat content measurement, the choice of the tempering procedure is very important, each of them leading to different values, because of different sample quantities and/or size of formed crystals.

Knowledge of the characteristics when the fat melts and crystallize and its chemical composition and physical properties is of great importance for a good quality and process control, as standards definition for each specific use. These data can be used in the development of new products.

When a fat is in the solid and/or liquid phase state several physical properties can be analyzed. Thermal behaviour of oils and fats and their physical properties determination by many methods have been investigated for years, leading to new methods which are accurate and fast, with sophisticated and modern instrumentation. These innovations not only complement but tend to substitute the older methods. Differential Scanning Calorimetry (DSC) is a useful technique for studying the thermal behaviour of oils and fats, being one of the most important methods of thermal analysis, besides it is fast and accurate. This technique is largely applied in chemical and pharmaceutical industries.

Many studies have been reported characterization and thermal behaviour of fats used in the formulation of margarines, such as storage temperature effect in the consistency of commercial margarine (Segura et al., 1990); characterization of hydrogenated sunflower oil (Herrera \& Añón, 1991); investigation of the relationship between cooling velocity and crystallization behaviour of hydrogenated sunflower oil (Herrera et al., 1992); investigation of tempering effects in slip melting point values of several oils, like palm and its fractions olein and stearin, and hydrogenated fat (Berger et al., 1982); characterization of palm oil and hydrogenated palm olein used in margarine formulations, measuring melting point, solid fat content and thermal behaviour by DSC (Yap et al., 1989). DeMan et al. (1989) analyzed physical characteristics and texture of margarines and shortenings and used DSC technique to verify peak temperature and crystallization temperature and enthalpy. In another study, DeMan et al. (1991), characterized shortenings, obtaining different melting curves for the several products. D'Souza et al. (1991) studied physico-chemical properties of fractions of oil phases of margarines, using DSC technique to investigate melting and crystallization behaviour of the original fat and its fractions.

\section{EXPERIMENTAL}

\section{Material}

8 different types of hydrogenated vegetable fats for margarine manufacturing were used, identified as $A, B, C, D, E, F, G$ and $H$.

\section{Methods}

Trans Isomers: AOCS method Cd14-61 (1993).

Calculated iodine value: AOCS method $\mathrm{Cd} 1 \mathrm{c}-85$ (1993).

Fatty acid composition: Values were obtained analysing methyl esters by gas-liquid chromatography. The instrument used was a Perkin Elmer Sigma 3B gas-liquid chromatograph with ionization detector and the results were obtained by a Perkin Elmer integrator $\mathrm{LCl}-100$. The methyl esters were obtained according to Hartman \& Lago (1973). Silar Column 10 C (1/8" diameter, length $4 \mathrm{~m}$ ) was used, with the following temperatures: column, $175^{\circ} \mathrm{C}$; detector, $225^{\circ} \mathrm{C}$ and carrying gas flow, $25 \mathrm{~mL} / \mathrm{min}$.

Solid Fat Content. by pNMR technique, according to AOCS Cd 16-81 (1993) and IUPAC 2.150 (1987) methods. The instrument used was a Bruker Minispec PC120 NMR spectrometer. Differences between the two methods tempering procedures can be observed in figure 1.
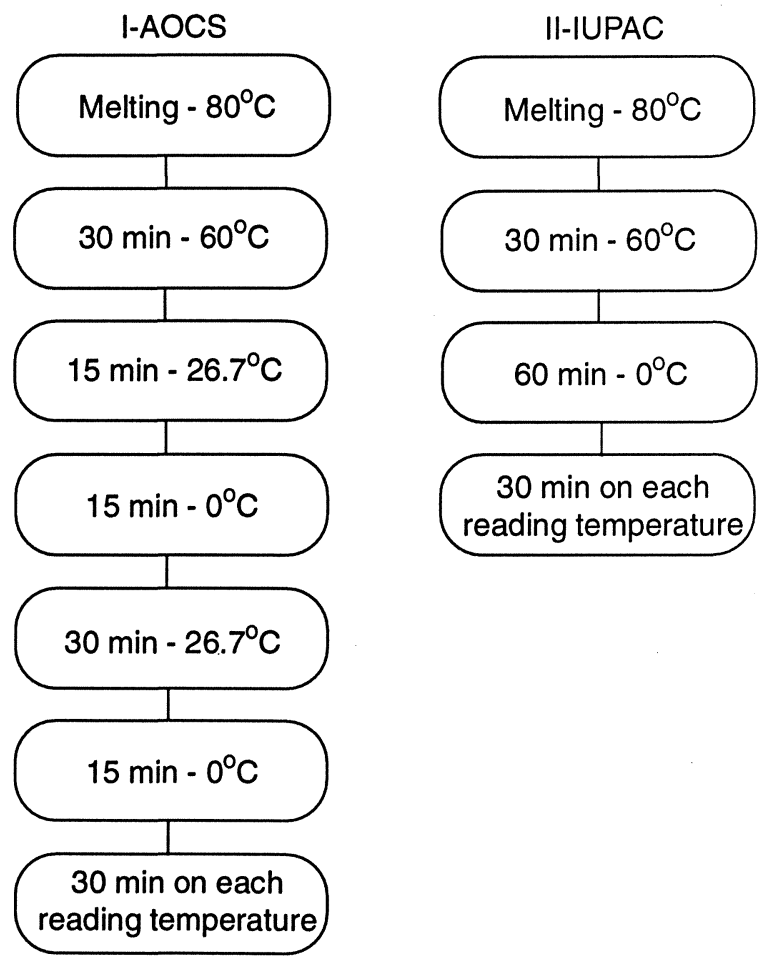

Figure 1

IUPAC and AOCS tempering methods 
Differential Scanning Calorimetry. The instrument used was a Perkin Elmer DSC7 Differential Scanning Calorimeter. Nitrogen was the carrier gas and calibration was done with indium, after checking the operation with distilled, deionized water. $10-15 \mathrm{mg}$ of sample were enclosed in hermetically sealed aluminum pans and run against air (empty pan) as reference.

Weight samples were 10-15 mg.Temperature range: -50 to $80^{\circ} \mathrm{C}$. DSC curves were obtained according to Dodd \& Tonge (1987). Initial temperature in the sample holder $50^{\circ} \mathrm{C}$. Holding the sample at $80^{\circ} \mathrm{C}$ for 5 minutes to destroy any previous crystalline structure. Sample was cooled at $10^{\circ} \mathrm{C} / \mathrm{min}$ to $-50^{\circ} \mathrm{C}$, and crystallization curve was obtained. After holding at $-50^{\circ} \mathrm{C}$ for 5 minutes heating curves were recorded from initial temperature to $80^{\circ} \mathrm{C}$ at the same rate. The resulting DSC data was collected and processed by the PE 3700 TADS System. The following parameters were measured: fusion and crystallization enthalpies, maximum peaks, onset temperatures, initial crystallization and final melting temperatures. Base line was traced from the beginning of the curve until its final. Areas were obtained by integration and temperatures by peak analysis. Melting temperature was considered as the final temperature recorded at the end of the curve while crystallization temperature was considered as the temperature where the curve has begun, in the beginning of crystallization.

\section{RESULTS AND DISCUSSION}

In nature, fatty acids are usually in the cis geometric form. In fats and oils of vegetable origin, trans isomers are not found, but only if these products had been submitted to chemical processes like hydrogenation (DeMan \& DeMan, 1983; Weiss, 1980). In table I, data of total number of geometric isomers of unsaturated fatty acids in all samples are in the range of 20 to $35 \%$. Fatty acid composition indicated great differences only in oleic and linoleic acids values, because of different hydrogenation intensities degrees, or different catalyzer action.

Calculated iodine values (Table I) showed that sample B has the highest value (108), being the more unsaturated and $C$ is the more saturated, with iodine value of 89 . Sample which were hydrogenated to a iodine value of 89 showed the lightest trans isomerization (35.6). If the initial raw material is soybean oil, the decreasing of 20 units of iodine value leads to a good product to be added to margarine formulation.

Solid fat content is one of the determinants of consistency, being the parameter which gives more or less hardness degree at a certain temperature. Hydrogenation and isomerization degree are associated to a increasing of solid fat content (Kheiri, 1984; Van den Enden et al., 1982). Figures 2 and 3 show solid fat content values of the 8 hydrogenated fats, through IUPAC and AOCS tempering procedures respectively. Thermal behaviour of the fats, presented the same profile, with a superior group with greater solid fat content $(C / E / G / H)$, an intermediate $(F)$ and an inferior $(A / B / D)$.

In figure 4, comparative thermal behaviour profile of 2 samples, analysed by AOCS and IUPAC tempering procedures, can be seen. Solid fat content curves obtained by IUPAC procedure showed higher values on temperatures of 10 and $21.1^{\circ} \mathrm{C}$. From $26.7^{\circ} \mathrm{C}$, solid

Table I

Fatty acid composition (\%w/w) and trans isomers content of hydrogenated fats

\begin{tabular}{crrrrrrrr}
\hline Fatty Acid & A & B & C & D & E & F & G & H \\
\hline C12:0 & 0.17 & - & - & - & - & - & - & - \\
C14:0 & 0.20 & 0.10 & 0.14 & 0.13 & 0.10 & 0.16 & 0.10 & 0.11 \\
C16:0 & 12.03 & 11.81 & 11.81 & 12.58 & 12.02 & 12.34 & 11.62 & 11.27 \\
C18:0 & 7.16 & 8.19 & 9.13 & 6.57 & 9.02 & 8.04 & 7.26 & 9.26 \\
C18:1 & 48.61 & 43.09 & 54.99 & 53.43 & 45.57 & 46.03 & 46.69 & 49.33 \\
C18:2t & 0.86 & 0.52 & 1.14 & 0.92 & - & - & - & 1.21 \\
C18:2 & 27.71 & 31.79 & 20.69 & 24.96 & 29.42 & 29.71 & 30.58 & 25.40 \\
C20:0 & 0.22 & 0.44 & 0.17 & 0.34 & 0.47 & 0.56 & 0.40 & 0.46 \\
C18:3 & 2.66 & 3.68 & 1.52 & 0.75 & 3.04 & 2.74 & 2.96 & 2.57 \\
C22:0 & 0.38 & 0.38 & 0.41 & 0.32 & 0.36 & 0.42 & 0.39 & 0.39 \\
\hline$\Sigma$ sat. & 20.16 & 20.92 & 21.66 & 19.94 & 21.97 & 21.52 & 19.77 & 21.49 \\
$\Sigma$ unsat. & 79.84 & 79.08 & 78.34 & 80.06 & 78.03 & 78.48 & 80.23 & 78.51 \\
\hline Calculated IV* & 98 & 108 & 89 & 93 & 98 & 98 & 101 & 95.2 \\
Trans isomers (\%) & 24.8 & 22.8 & 35.6 & 25.5 & 23.4 & 23.6 & 25.3 & 30.5 \\
\hline
\end{tabular}

* Calculated lodine Value. 


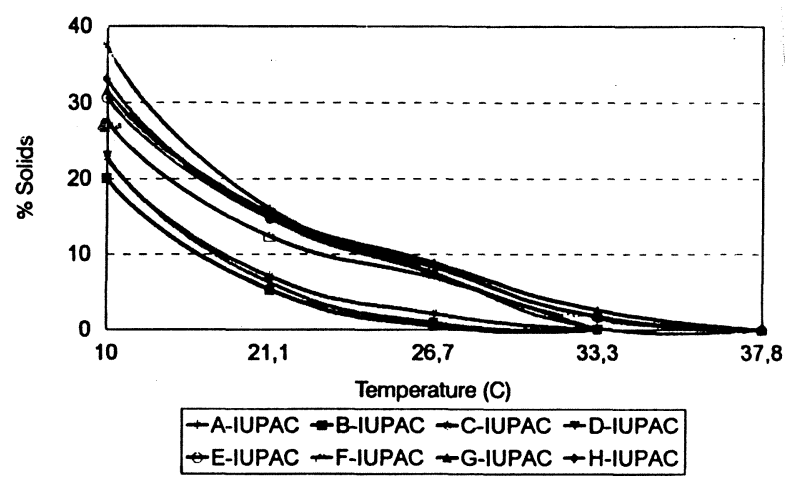

Figure 2

Solid temperature curves by IUPAC method

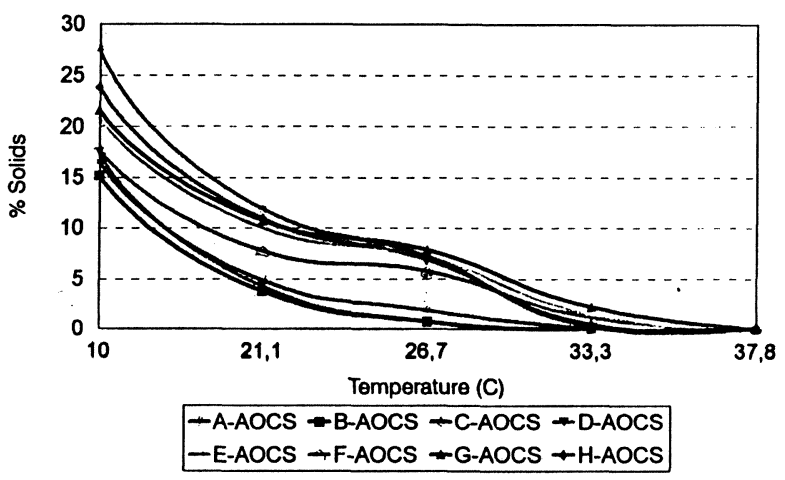

Figure 3

Solid temperature curves by AOCS method

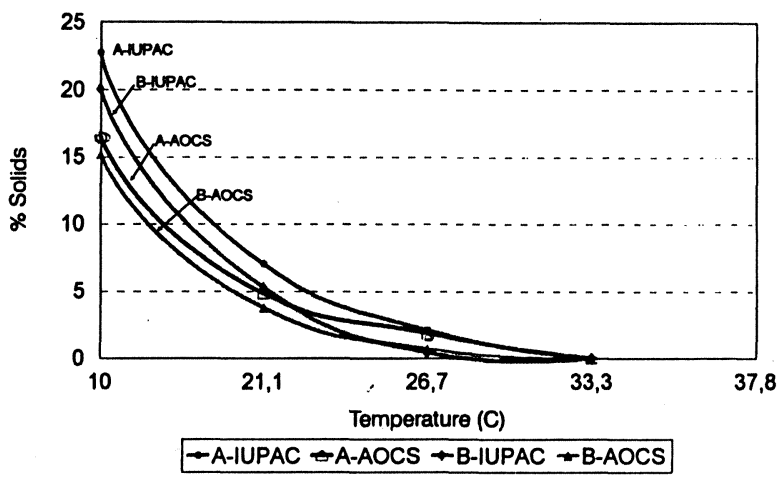

Figure 4

Comparative solid temperature curves for IUPAC and AOCS methods for samples " $A$ » and «B» fat content curves obtained by both procedures had the same behaviour. These different behaviours are explained by the different tempering procedures used. In IUPAC tempering procedure, samples are submitted to a great temperature variation in a short period of time, which leads to formation of greater crystals in few quantities when comparing to AOCS procedure, where tempering procedure is gentle.

Figures 5 and 6 show melting and crystallization curves obtained by DSC technique.

Due to hydrogenation, all samples had a large fusion peak, suggesting a large melting range. Hydrogenation process produces trans fatty acids, which contributes to a greater number of geometric and positional isomers. Consequently, this fact modifies the triglycerides distribution. The rearrangement of tryglicerides and the presence of trans fatty acids increase the melting range. In melting curves (figure 5) some differences are observed. Samples can be separated in two groups, with great differences in melting point of triglycerides. Samples $A, C, D$, and $H$ had homogeneous groups identified by two large peaks. Samples $B$ and $G$ showed a very unsaturated triglycerides group, followed by two other ones with greater saturation degree. Samples $\mathrm{E}$ and $\mathrm{F}$ also had this initial group, but they are not so relevant.

Similar thermograms are observed for crystallization curves (figure 6), with a sharp characteristic peak, always presented in the crystallization or more saturated triglycerides. Sharpness intensity of this peak was greater in C sample curve.

Onset, peak, crystallization and melting temperatures are shown in tables II and III. Different values observed when comparing temperatures and enthalpies for the samples can be attributed to the various hydrogenation degrees. Melting temperatures varied from 37.1 to $43.8^{\circ} \mathrm{C}$; Crystallization temperatures, from 14.3 to $22.6^{\circ} \mathrm{C}$ and crystallization onset temperature, 10.4 to $17.4^{\circ} \mathrm{C}$. In the case of melting curves, differences observed in peak temperatures for samples $\mathrm{C}$ and $\mathrm{H}$ are result of curves shapes, where the considered peak for calculations was the highest one. Crystallization peak temperatures varied from 7.9 to $14.8^{\circ} \mathrm{C}$.

Melting enthalpy is the required energy for melting the sample completely. Higher values of melting enthalpies indicate fats which are more difficult to melt in analysis conditions. In crescent order samples can be classified as $A<F<E<B<D<H<G$ $<C$, with melting enthalpies varying form 51.28 to 76.5 $\mathrm{J.g}^{-1}$. Crystallization enthalpies indicates released energy during the phenomenon. Crystallization enthalpies values ranged from -18.92 to -34.16 J. $\mathrm{g}^{-1}$. The order for samples was $F<A<B<D<E$ $<H<G<C$. Results for crystallization did not have any correlationship with the melting ones. This fact indicates that samples have different behaviour in melting and crystallization. 

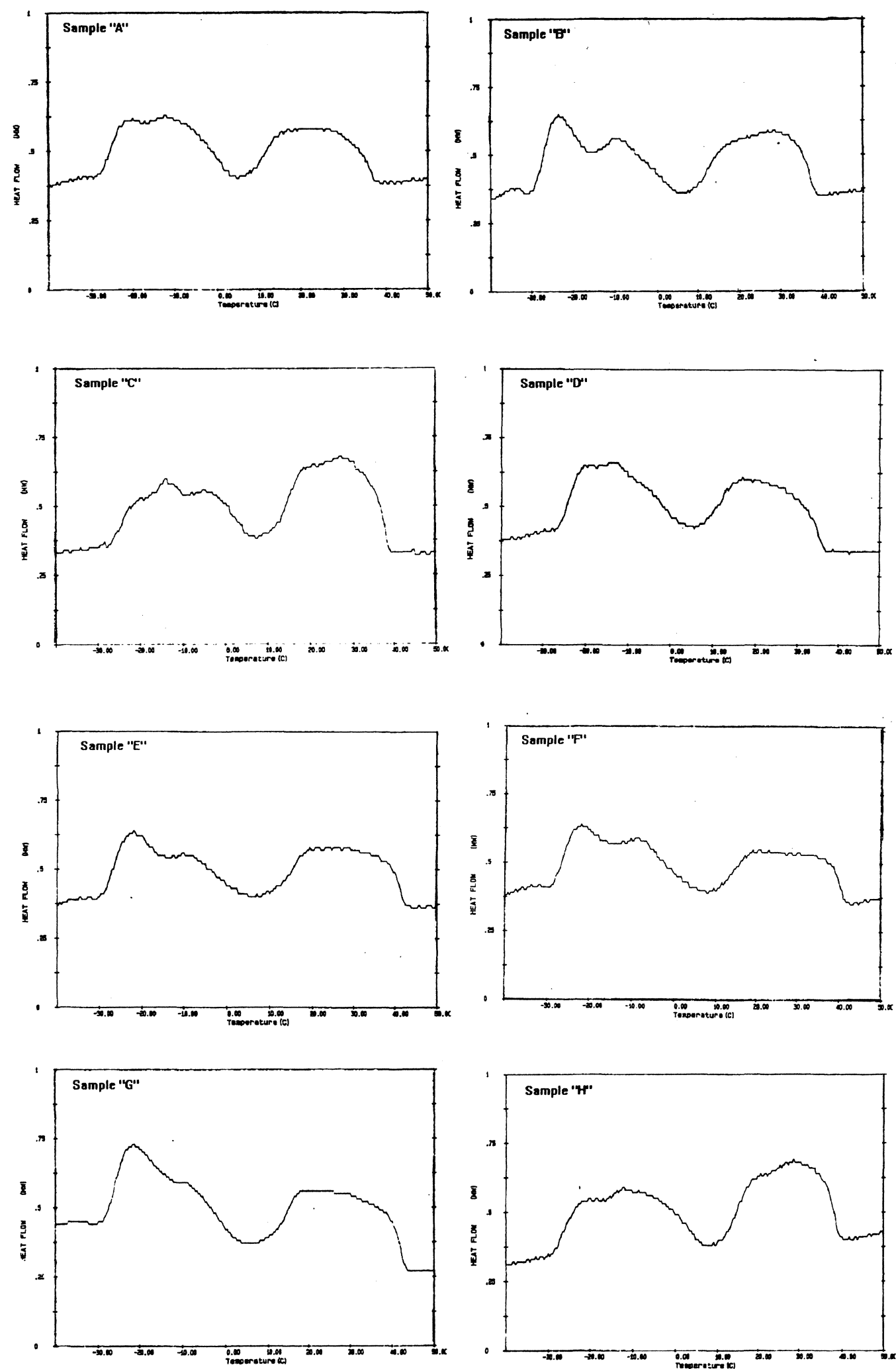

Figure 5

DSC melting curves 

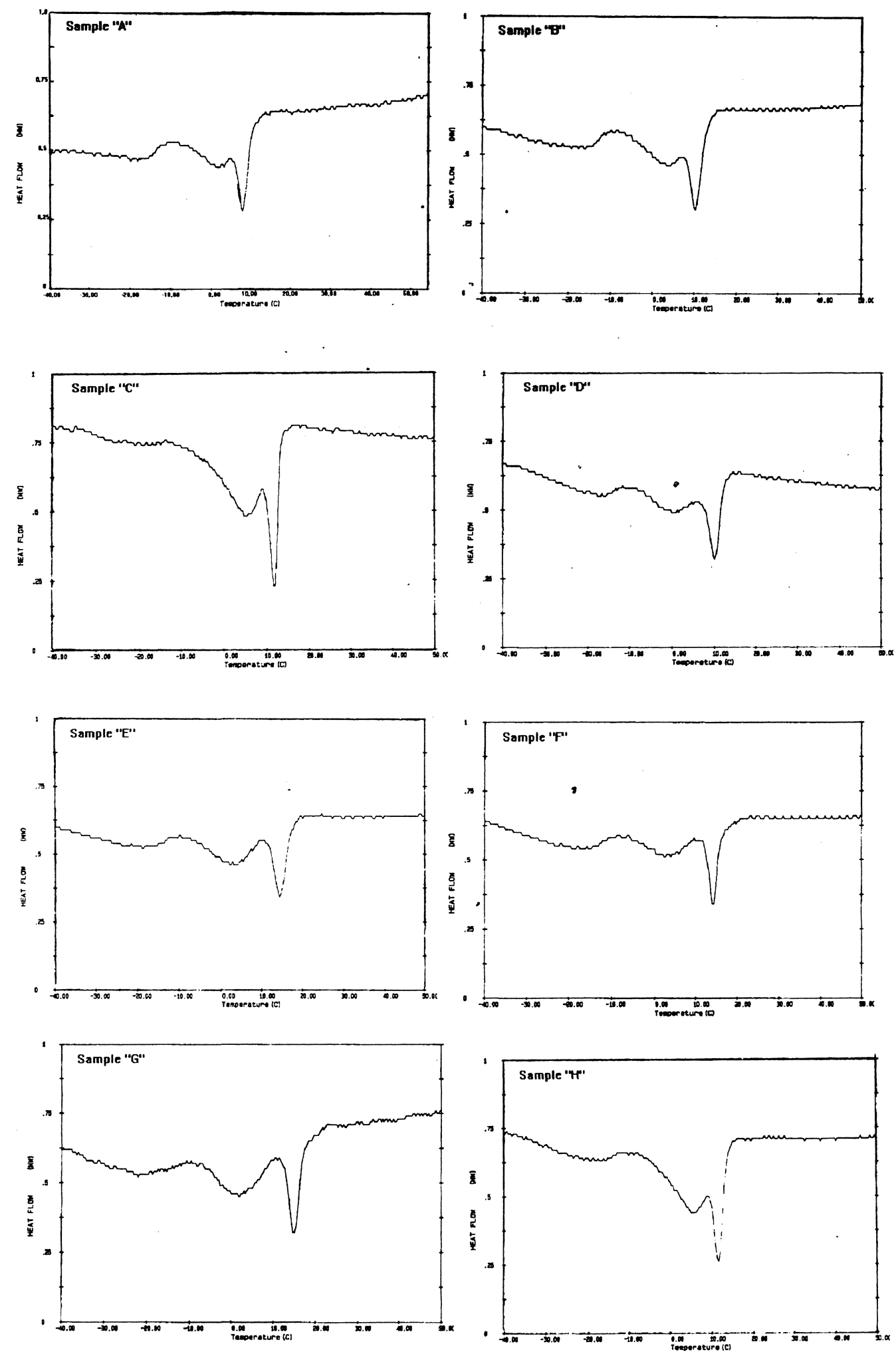

Figure 6

DSC crystallization curves 
Table II

Data obtained by DSC crystalizattion curves $\left(10^{\circ} \mathrm{C} \mathrm{min}{ }^{-1}\right)$

\begin{tabular}{ccccc}
\hline Samples & $\begin{array}{c}\text { Initial } \\
\text { crystalizattion } \\
\left({ }^{\circ} \mathrm{C}\right)\end{array}$ & $\begin{array}{c}\text { Onset } \\
\text { temperature } \\
\left({ }^{\circ} \mathrm{C}\right)\end{array}$ & $\begin{array}{c}\text { Peak } \\
\text { temperature } \\
\text { pico }\left({ }^{\circ} \mathrm{C}\right)\end{array}$ & Entalphie $\left(\mathrm{J} . \mathrm{g}^{-1}\right)$ \\
\hline A & 14.3 & 10.4 & 7.9 & -19.34 \\
$\mathrm{~B}$ & 14.9 & 13.0 & 10.3 & -21.74 \\
$\mathrm{C}$ & 15.6 & 13.4 & 11.8 & -34.16 \\
$\mathrm{D}$ & 14.5 & 12.2 & 9.9 & -21.82 \\
$\mathrm{E}$ & 19.1 & 17.2 & 14.4 & -22.14 \\
$\mathrm{~F}$ & 20.3 & 16.0 & 14.2 & -18.92 \\
$\mathrm{G}$ & 22.6 & 17.4 & 14.8 & -31.06 \\
$\mathrm{H}$ & 14.8 & 13.6 & 11.6 & -27.86 \\
\hline
\end{tabular}

Table III

Data obtained by DSC melting curves $\left(10^{\circ} \mathrm{C} \mathrm{min}^{-1}\right)$

\begin{tabular}{ccccc}
\hline Samples & $\begin{array}{c}\text { Initial } \\
\text { melting point } \\
\left({ }^{\circ} \mathrm{C}\right)\end{array}$ & $\begin{array}{c}\text { Onset } \\
\text { temperature } \\
\left({ }^{\circ} \mathrm{C}\right)\end{array}$ & $\begin{array}{c}\text { Peak } \\
\text { temperature } \\
\left({ }^{\circ} \mathrm{C}\right)\end{array}$ & Entalphie $\left(\mathrm{J} . \mathrm{g}^{-1}\right)$ \\
\hline $\mathrm{A}$ & 37.4 & -27.5 & -12.2 & 51.28 \\
$\mathrm{~B}$ & 38.9 & -28.7 & -23.3 & 59.70 \\
$\mathrm{C}$ & 39.8 & -26.1 & 27.2 & 76.50 \\
$\mathrm{D}$ & 37.1 & -26.0 & -14.5 & 64.58 \\
$\mathrm{E}$ & 42.9 & -28.7 & -22.0 & 57.88 \\
$\mathrm{~F}$ & 42.8 & -28.0 & -22.0 & 55.56 \\
$\mathrm{G}$ & 43.8 & -27.8 & -21.5 & 70.20 \\
$\mathrm{H}$ & 40.2 & -28.3 & 28.7 & 67.02 \\
\hline
\end{tabular}

\section{CONCLUSIONS}

Comparison of the data obtained showed that solid fat content values must be considered according to the tempering method used. For temperatures lower than ambient, data obtained from melting curve of fats showed lower values $(30-40 \%)$ when submmited to AOCS procedure. Statistical studies with greater number of samples may lead to a correlation formula for comparison between these two procedures.

Thermal analysis of hydrogenated fats by DSC technique is an important tool for research in this area, being a very accurate technique for detecting some little differences of industrially used fats, giving an indication for manufacturers about interactions between these products.
Although samples analyzed are all indicate for margarine formulations, melting and crystallization enthalpies were characteristic for each sample.

\section{BIBLIOGRAPHY}

AOCS (1993). - "Official Methods and Recommended Practices of the American Oil Chemists' Society".- v. 1-2.

Barrera-Arellano, D., Block, J. M. (1993). -«Acidos grasos trans en aceites hidrogenados: implicaciones técnicas y nutricionales".- Grasas y Aceites 44, 286-293.

Berger, K. G., Siew, W. L., Oh, C. H. (1982). - «Factors affecting slip melting point of palm oil products".- J. Am. Oil Chem. Soc. 59 (5), 244-249.

D'Souza, V., DeMan, L., DeMan J. M. (1991). -“Chemical and physical properties of the high melting glyceride fractions of commercial margarines".- J. Am. Oil Chem. Soc. 68 (3), 153-162. 
DeMan, L. \& DeMan, J. M. (1983). - “Trans fatty acids in milkfat".- J. Am. Oil Chem. Soc. 60 (6), 1095-1098.

DeMan, L., DeMan, J. M., Blackman, B. (1989). -«Physical and textural evaluation of some shortening and margarines".J. Am. Oil Chem. Soc. 66 (1), 128-132.

DeMan, L., DeMan, J. M., Blackman, B. (1991). -«Physical and textural characteristics of some North American shortenings".- J. Am. Oil Chem. Soc. 68 (2), 63-69.

Dodd, J. W. \& Tonge, K. H. (1987). - «Thermal methods».London, John Wiley \& Sons. $337 \mathrm{p}$.

Hartman, L. \& Lago, R. C. (1973). -«Rapid determination of fatty acid methyl esters from lipids».- Lab. Practice 22 (8), 475-476, 494.

Herrera, M. L. \& Añón, M. C. (1991). «Crystalline fractionation of hydrogenated sunflowerseed oil. II. Differential Scanning Calorimetry (DSC)».- J. Am. Oil Chem. Soc. 68 (11), 799-803.

Herrera, M. L., Segura, J. A., Rivarola, G. J., Añón, M. C. (1992). - «Relationship between cooling rate and crystallization behavior of hydrogenated sunflowerseed oil».J. Am. Oil Chem. Soc. 69 (9), 898-905.

IUPAC (International Union of Pure and Applied Chemistry). (1987). - «Standard Methods tor the Analysis of Oils, Fats and Derivatives".- 7th. ed.- Blackwell Scientific Publications-Oxford.
Kheiri, M. S. A. (1984). -«Hydrogenation».- Porim Technol. Palm Oil Res. Inst. Malaysia 10 (6), 26-39.

Segura, J. A., Herrera, M. L., Añón, M. C. (1990). -«Storage of commercial margarine at different temperatures".J. Am. Oil Chem. Soc. 67 (12), 989-992.

Valenzuela A., King, J., Nieto, S. (1995). - «Trans fatty acid isomers from hydrogenated fats: the controversy about health implications".- Grasas y Aceites 46, 369-375.

Van den Enden, J. C., Haighton, A. J., Van Putte, K., Vermaas, L. F., Waddington, D. (1982). - «A method for the determination of the solid phase content of fats using Pulsed Nuclear Magnetic Resonance».- Fette Seif. Anstrichm. 80 (5), 180-186.

Weiss, T. J. (1980). - «Food Oils and their uses».-2 ed. AVI, Chichester, $310 \mathrm{p}$.

Yap, P. H., DeMan, J. M., DeMan, L. (1989). -“Chemical and Physical properties of palm oil and palm olein as affected by hidrogenation».- Can Inst. Food Sci. Tech. J. 22 (3), 243-248.
Recibido: Mayo 1997 Aceptado: Noviembre 1997 